\title{
Effects of combined conservation practices on soil and water quality in the Central Mississippi River Basin
}

\author{
C. Baffaut, F. Ghidey, R.N. Lerch, K.S. Veum, E.J. Sadler, K.A. Sudduth, and N.R. Kitchen
}

\begin{abstract}
Conventional cultivation of claypan soils leads to soil and water quality degradation because of high runoff and associated soil erosion. The Goodwater Creek Experimental Watershed, which is part of the USDA Agricultural Research Service Benchmark Conservation Effects Assessment Project, Watershed Assessment Studies, was established to address these issues. Plot studies have highlighted trade-offs between erosion control and herbicide or nutrient runoff. There is a need for long-term field-scale evaluation of combined practices that reduce sediment, nutrient, and herbicide losses by runoff. A 36 ha field located in Missouri was under a conventional corn (Zea mays L.)-soybean (Glycine max L.) system from 1993 to 2003 with fertilizer application and tillage prior to planting in the spring. A precision agriculture system defined by two main management zones was implemented from 2004 to 2014: wheat (Triticum aestivum L.) and soybean in $60 \%$ of the field, and corn and soybean in the remaining $40 \%$. The system included no-till, cover crops, atrazine split-applications based on weed pressure, variable rates of nitrogen $(\mathrm{N})$, and variable rates of fall-applied phosphorus $(\mathrm{P})$. The objective of this study was to compare runoff water quality from the two management systems, based on flow and load duration curves, cumulative distribution functions, and conclusions from replicated plot studies. The precision agriculture system did not affect annual runoff, but it did increase the frequency of low flows. Sediment losses were reduced by $87 \%$ as a result of no-till and cover crops. Atrazine and $\mathrm{P}$ losses were lower than expected, despite the lack of incorporation into the soil. Atrazine losses were possibly lower because of the wheat area acting as a buffer, greater atrazine adsorption and retention in the field, and faster decay. Dissolved P losses as a fraction of applied remained the same, likely because of greater adsorption and lower runoff risk when applying P. Finally, nitrate- $\mathrm{N}\left(\mathrm{NO}_{3}-\mathrm{N}\right)$ losses decreased and resulted in an overall decrease of $\mathrm{N}$ losses despite a slight increase of ammonium-N $\left(\mathrm{NH}_{4}-\mathrm{N}\right)$ losses. Explanations included a greater soil water content, a different timing of $\mathrm{N}$ applications, and $\mathrm{N}$ uptake by cover crops. Building on these successes, an aspirational management system is proposed to further improve on the performance and practicality of the precision agriculture system.
\end{abstract}

Key words: conservation practices — cover crops—no-till—nutrient management—precision agriculture-water quality

The Central Claypan Area (Major Land Resource Area 113) encompasses 3 million ha in northeastern Missouri and south-central Illinois (USDA NRCS 2006) (figure 1). The area is dominated by high runoff potential claypan soils, and soil and water quality degradation within the northeastern Missouri portion of the region has been well documented over the last 20 years (Sadler et al. 2015; Veum et al. 2015). The Salt River Basin encompasses the major-

The Central Claypan Area has the highest estimated soil erosion rates for cropland within the state (Willett et al. 2012). Because of the soil and water quality degradation, this region was one of the sites chosen for both the Conservation Effects Assessment Project (CEAP) (Lerch et al. 2008) and the LongTerm Agroecosystem Research (LTAR) project (Sadler et al. 2015). One focus of CEAP was to conduct watershed-scale assessments to determine the collective effects of existing conservation practices on trends in water quality (Lerch et al. 2011a, 2011b, 2015a) as well as to identify sources of contaminants (Willett et al. 2012; Peacher et al. 2018) to support future targeting efforts.

The $72 \mathrm{~km}^{2}$ Goodwater Creek Experimental Watershed is located in the headwaters of the Salt River Basin. Overall, long-term changes in water quality at the watershed scale were modest and attributed to changes in herbicide usage, fertilizer management, and land use. For example, trends in herbicide concentrations were only observed when major changes in usage occurred in the watershed (Lerch et al. 2011a). Similarly, decrease in nutrient transport were attributed to land use changes and improved nitrogen $(\mathrm{N})$ fertilizer management in the watershed, which shifted the amount, timing, and placement of fertilizer applications (Lerch et al. 2015a).

Two factors help explain the limited improvements in water quality observed in Goodwater Creek. One is the importance of streambank erosion as sources of sediment and nutrient contamination. A study in two watersheds within the Salt River Basin showed that streambanks contributed an average of $83 \%$ of sediment, $67 \%$ of total phosphorus (P), and 23\% of the total $\mathrm{N}$ transported from these watersheds underlain by claypan soils (Willett et al. 2012; Peacher et al. 2018). Thus, cropped fields may not currently be the major source of sediment and $\mathrm{P}$ within these watersheds, and practices that stabilize streambanks will be needed to see improvements in stream water quality.

ity of the Missouri portion of the Central Claypan Area, and numerous studies have documented significant stream and groundwater contamination by sediment (Baffaut et al. 2013), nutrients (Kitchen et al. 2015; Lerch et al. 2015c), and herbicides (Blanchard and Lerch 2000; Lerch et al. 2011b) within the basin. Long-term studies within the region have documented soil degradation in systems with intensive tillage, two-year crop rotations, and high chemical inputs (Veum et al. 2015).
Claire Baffaut is a research hydrologist, Fessehaie Ghidey is an agricultural engineer, Robert $\mathbf{N}$. Lerch is a research soil scientist, Kristen $\mathbf{S}$. Veum is a research soil scientist, E. John Sadler is a research soil scientist and research leader, Kenneth A. Sudduth is an agricultural engineer (retired), and Newell R. Kitchen is a research soil scientist, all at the USDA Agricultural Research Service Cropping Systems and Water Quality Research Unit, Columbia, Missouri. 


\section{Figure 1}

Major Land Resource Area 113, Salt River Basin, and Goodwater Creek Experimental Watershed.

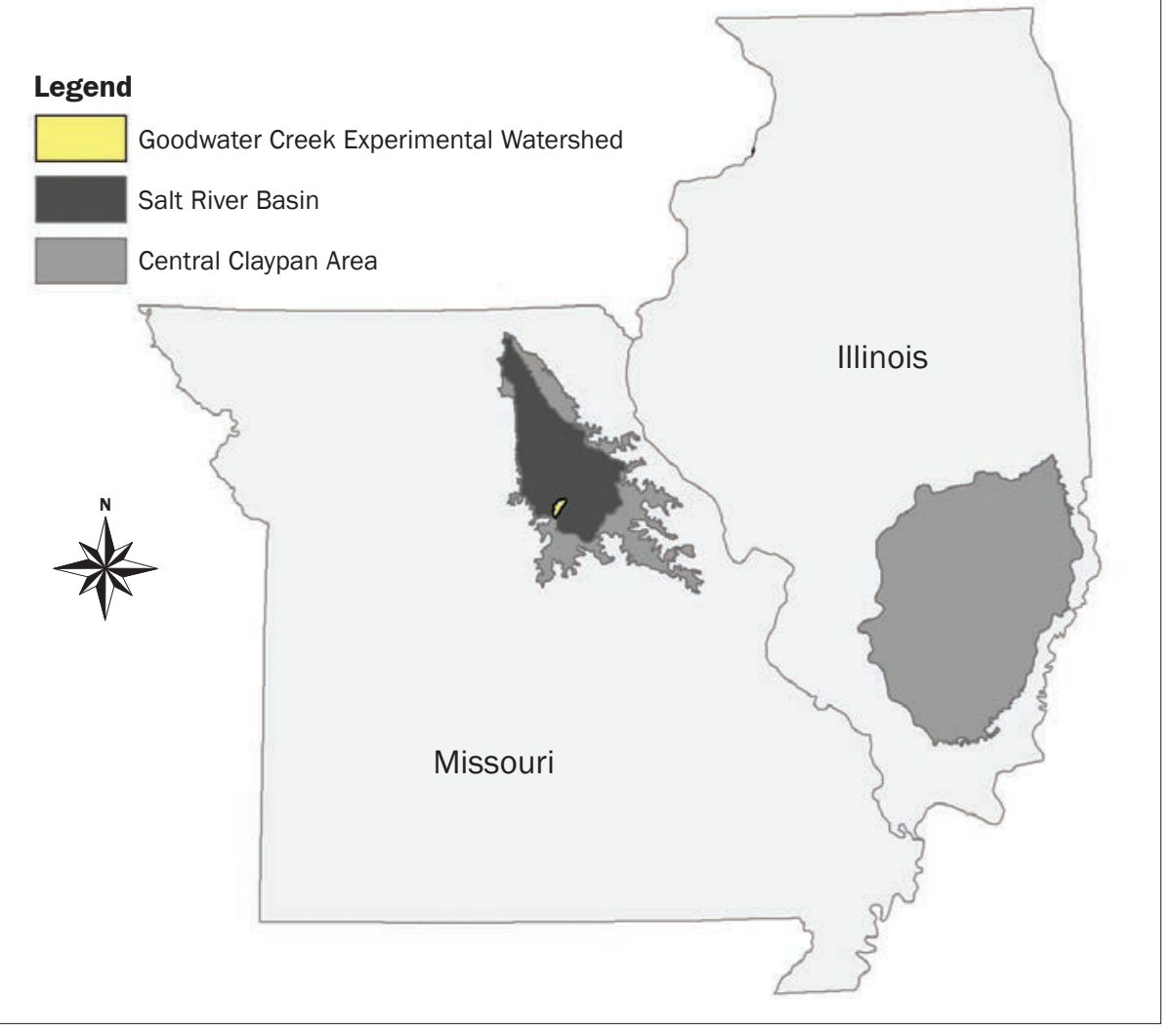

Another factor is the extent of conservation practice implementation. In 2006, 14.7\% of the Goodwater Creek Experimental Watershed was protected by at least one conservation practice (Lerch et al. 2011a). Assuming the same implementation rate as occurred between 1990 and 2006, there may currently be $23 \%$ of the watershed protected by the time of this writing. Moreover, practices heavily focused on grass waterways and terraces, which are very effective for field erosion control but have limited effect on dissolved-phase herbicide or nutrient transport. They are also among the most costly conservation practices to implement. There is a need for practices that producers are willing to implement and that control erosion as well as reduce nutrient and herbicide transport. Plot studies have highlighted trade-offs between practices designed to reduce edge-of-field transport of specific constituents. One major trade-off concerns no-till, which is effective at reducing soil erosion, but increases the transport of surface applied herbicides (Ghidey et al. 2005; Lerch et al. 2013) and dissolved P (Smith et al. 2015; Verbree et al. 2010). Thus, there is a need to evaluate the combined effect of multiple practices on water quality with the goal of addressing multiple contaminants and transport modes (i.e., dissolved-phase versus sediment-bound).

One approach to an integrated system of practices that could sustain production yet benefit water quality is a precision agriculture system (PAS). Using profitability data analysis, Kitchen et al. (2005) developed a comprehensive PAS for a 36 ha field located in the Goodwater Creek Experimental Watershed. From 1993 to 2003, the field was managed under a conventional system that represented the dominant cropping practices in the region: a corn (Zea mays L.)-soybean (Glycine $\max$ L.) rotation with high chemical inputs and intensive tillage. The depth of topsoil above the claypan, a dense and high clay content layer with very low permeability (Kitchen et al. 1999), has been linked to runoff generation and associated transport of pollutants (Lerch et al. 2005) as well as to productivity (Kitchen et al. 2005) on this field. The spatial variability in topsoil depth is related to soil loss over the last 100 to 150 years within the field, and controls the soil quality and crop productivity patterns currently observed. It may also control water quality, as Mudgal et al. (2012) demonstrated using a simulation model.
The PAS design included three zones with one management system for zones A and $\mathrm{B}$ (figure 2), and one for zone C, based on the expectation that these systems would improve profitability and conserve soil and water resources. The PAS was targeted to these areas with the following objectives: (1) reduce production costs while stabilizing crop yields and improving crop water use efficiency; (2) improve surface runoff quality by reducing sediment, herbicide, and nutrient loss; (3) reduce the leaching of nitrates $\left(\mathrm{NO}_{3}\right)$ to groundwater; and (4) improve soil quality by reducing topsoil loss, improving soil structure and infiltration, and building organic matter. After 11 years of PAS on this field, Yost et al. (2017) concluded that the greatest production benefit of PAS was reduced temporal variability of yields. They did not observe improvement in yields. Yet, profitability was sustained (Yost et al. 2019) in spite of the additional costs incurred under the PAS. Producers and farm land owners would most likely be motivated to implement these practices because of reduced variability (and therefore uncertainty) in profitability and income. Enhancements of soil and water quality by the PAS are desirable environmental outcomes that need to be evaluated.

One challenge of field experiments is to have access to replicated fields for statistical comparison of the treatments. Helmers et al. (2012) used a balanced incomplete block design conducted at three locations across 12 field-size row crop watersheds in Iowa to study the effects of varying filter strip size and placement on contaminant transport in runoff. This highlights the difficulty in designing a replicated catchment experimental study with a randomized complete block design. An alternative is to define blocks and drainage areas that are sufficiently small to be replicated within a larger area and randomly assigned a treatment (Bosch et al. 2012). Such designs can result in drainage areas too small to address the problem of spatial variability within a drainage area. Another is to have paired watersheds (Udawatta et al. 2011), in which a baseline period is used to derive the relationship between the outcome in two or more watersheds, and a treatment period is used to investigate the effect of a specific treatment in one of the watersheds.

Implementing treatments successively in the same field or watershed is another option: these designs are sometimes called pre-post, before-after, or paired in-time. Analysis 


\section{Figure 2}

Average long-term profitability map (left) and crop management zones (right) identified to target production and conservation priorities of the Precision Agriculture System. For detailed description of these management zones, see Kitchen et al. (2005).
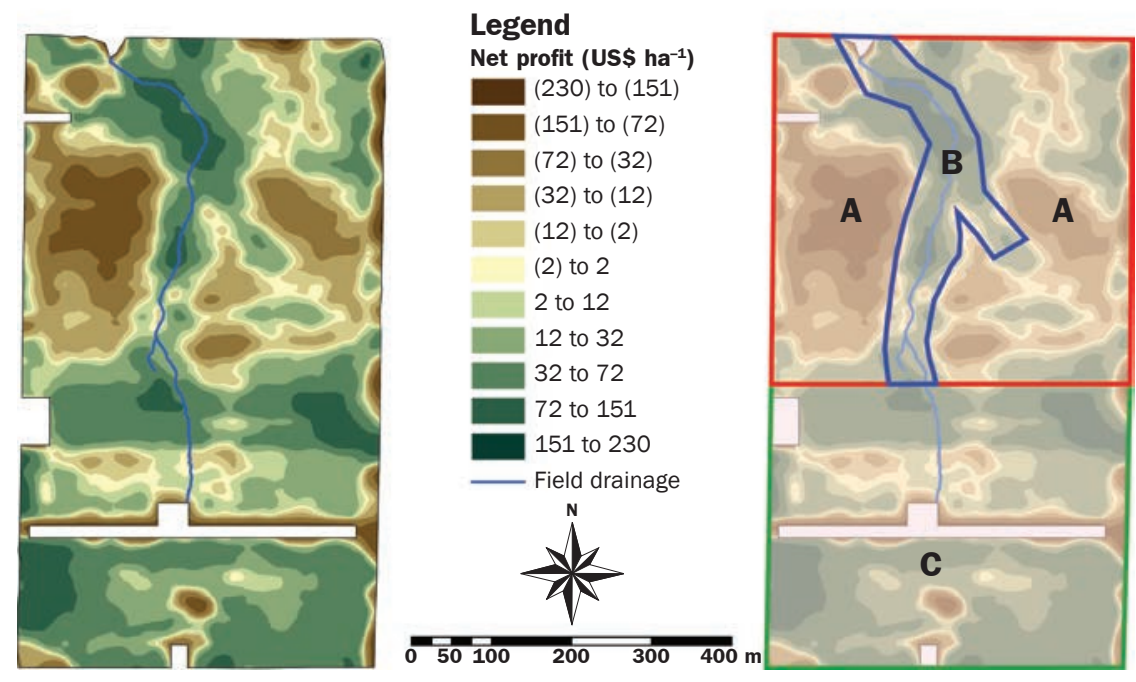

of variance techniques cannot be applied because the data points for each treatment are not independent of each other nor are treatments randomly assigned to experimental units. However, the data can be analyzed on the basis of cumulative distribution functions (Spooner et al. 1985).

This is the approach used in this study, in which we use statistical methods based on daily runoff and export of sediment and nutrients to compare the impacts of management over the two periods. The goal of this study was to compare the environmental impacts of the conventional and PAS management systems on the same field over separate 11-year periods (1993 to 2003 for conventional and 2004 to 2014 for PAS). Specific objectives of this study were to (1) compare runoff discharge and water quality over the two periods, and (2) use adjacent replicated plot studies on soil and water quality to inform the results.

\section{Materials and Methods}

Study Field. The area under study is a 36 ha field located in Boone County in Missouri (39¹3'48” N, 9207'12” W). The field soils and topography are characteristic of those found on a dominant fraction of the cropland in the Goodwater Creek Experimental Watershed:low slopes $(<3 \%)$ and claypan soils that belong to the Adco-Mexico-Putnam association. In this field, the top of the claypan was found at depths ranging from the soil surface on the steepest parts of the field to as much as $100 \mathrm{~cm}$ around the channel at the bottom of the field. Average annual precipitation over the study period (1993 to 2014) was $1,022 \mathrm{~mm}$, and average annual minimum and maximum daily temperatures were $6.8^{\circ} \mathrm{C}$ and $17.6^{\circ} \mathrm{C}$, respectively.

During the conventional period, the field was managed under a corn-soybean rotation with fertilizer application and tillage prior to planting in the spring. In 1995, heavy spring rains prevented timely planting of corn, and a sorghum (Sorghum bicolor L.) crop was planted in late June. In addition, a tillage operation took place in December of 1995 to address the soil compaction caused by the heavy spring rains. Otherwise, tillage occurred in the spring: one or two passes (disk or cultivator) prior to planting to loosen the ground, kill weeds, and prepare the seedbed, and one pass just before planting to incorporate fertilizers and herbicides. Fertilizer applications were uniform throughout the field and made during the corn year of the rotation (table 1). Fertilization usually consisted of preplant broadcast liquid urea-ammonium nitrate (UAN) solution, inorganic P (either diammonium phosphate [DAP] or monoammonium phosphate [MAP]), potassium (K), and lime, which were then incorporated by tillage. Herbicides included atrazine and alachlor or metolachlor on corn, and alachlor or metolachlor and imazaquin on soybeans. Table 1 shows the application rates of agricultural inputs considered in this study: N, P, and atrazine.

During the PAS period, the crop area was divided into three zones (figure 2): a wheat (Triticum aestivum L.)-soybean rotation in zones A and B (21 ha or $60 \%$ of the field) where corn had been found unprofitable for the most part, and a corn-soybean rotation in zone C (15 ha or $40 \%$ of the field). Both cropping systems included winter or summer cover crops as needed, and there was no use of tillage for any of the crops. One exception to that protocol occurred in August of 2007 when sediment was leveled to mitigate pooling of water in the area immediately above the weir, resulting in soil disturbance. Zone B included the land around the drainage channel of the field. For practicality reasons, zone B was initially managed with the same system as in zone A (soybean-wheat) but included permanent stiff-stem grasses planted at critical points along the drainage channel to control erosion. Herbicide applications for the grain crops caused the stiff-stem grasses to practically disappear by 2008 , a time by which benefits from no-till and cover crops had become sufficient to not require specific management in zone $\mathrm{B}$.

Both $\mathrm{N}$ and herbicide applications were split between planting and in-season (table 2). Nitrogen fertilization for corn and wheat included surface-applied UAN at planting and in-season top-dress applications with variable rates as a function of need determined using commercial ground-based crop canopy light reflectance sensors (USDA NRCS 2009; Kitchen et al. 2010). A small amount of starter fertilizer was placed with
Table 1

Fertilizer and atrazine herbicide rates applied on corn under the conventional system from 1993 to 2003.

\begin{tabular}{|c|c|c|c|}
\hline Year & Nitrogen $\left(\mathrm{kg} \mathrm{ha}^{-1}\right)$ & $P\left(P_{2} O_{5}\right)\left(k g ~ h a^{-1}\right)$ & Atrazine $\left(\mathrm{kg} \mathrm{ha}^{-1}\right)$ \\
\hline 1993 & 190 & $43(99)$ & 2.24 \\
\hline 1995 (sorghum) & 123 & $27(61)$ & 1.94 \\
\hline 1997 & 190 & None & 2.47 \\
\hline 1999 & 190 & None & 2.24 \\
\hline 2001 & 190 & $39(90)$ & 1.94 \\
\hline 2003 & 190 & $12(27)$ & 2.24 (split application) \\
\hline
\end{tabular}




\section{Table 2}

Tillage, atrazine, and nitrogen $(\mathrm{N})$ and phosphorus $(\mathrm{P})$ management for the precision agriculture system from 2004 to 2014 .

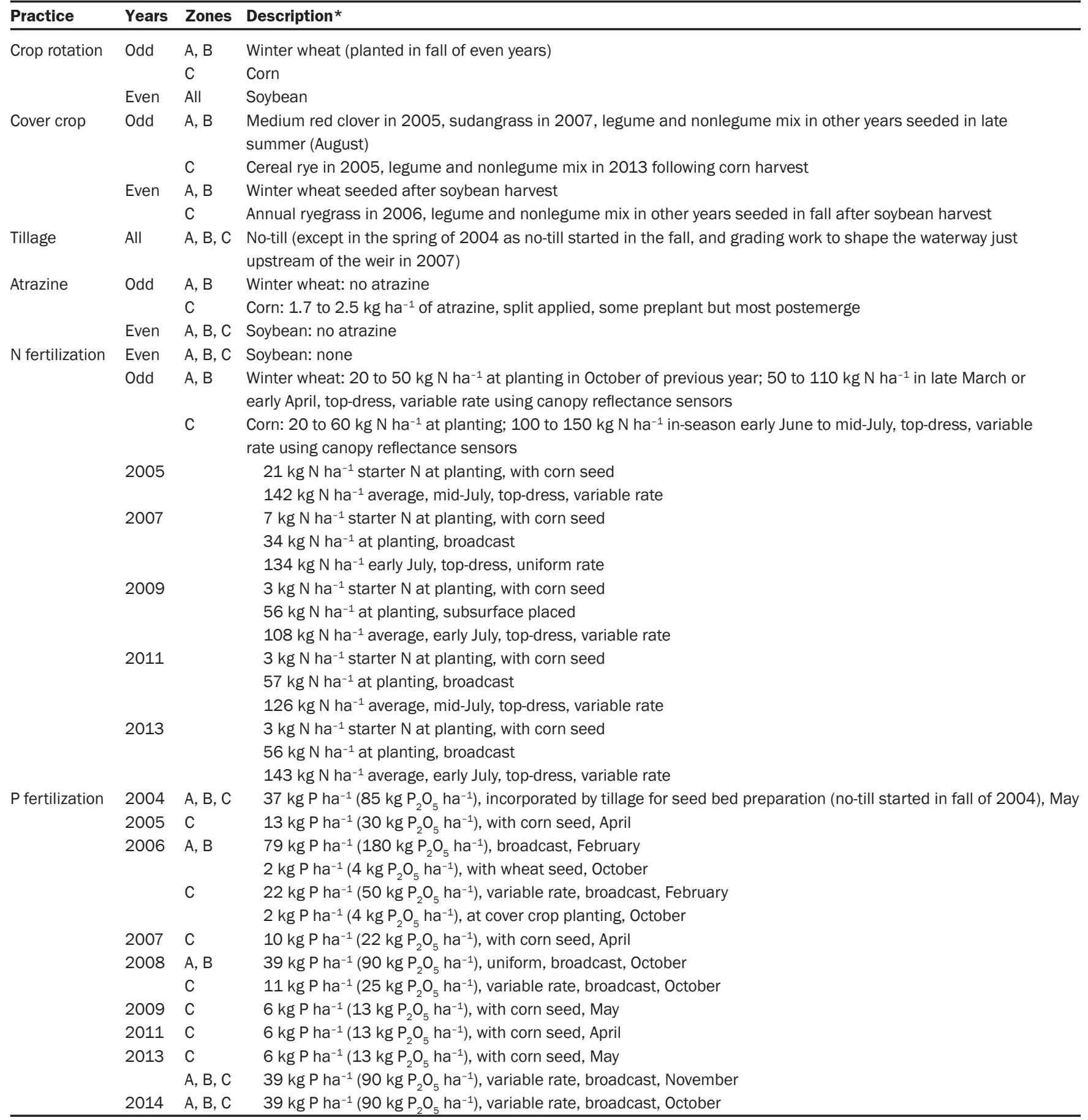

*Cereal rye (Secale cereals L.); medium red clover (Trifolium pratense L.); annual ryegrass (Lolium multiflorum Lam.); and sudangrass (Sorghum sudanense P. Stapf).

the seed at planting. In 2009, subsurface application of $\mathrm{N}$ fertilizer at planting was implemented to decrease volatilization losses. This was not repeated in 2011 and 2013 because of practical issues with the subsurface application, which resulted in uneven appli- cation rate. Instead, a volatilization inhibitor was added each time that $\mathrm{N}$ fertilizer was surface applied. In-season side-dressed $\mathrm{N}$ was dribbled on the ground surface near the plant instead of being knifed-in because the size of the plants at the time of the operation required a high-clearance applicator, and the one available could not support soil-engaging tools. Although sensor-controlled $\mathrm{N}$ application is possible earlier in the season when a tractor system can be used for subsurface fertilizer placement, later application is advantageous 
both to better synchronize $\mathrm{N}$ application with corn $\mathrm{N}$ uptake and to improve the sensitivity of sensor measurements to crop $\mathrm{N}$ differences (Kitchen et al.2010). Table 2 includes rates for the compounds considered in this study: N, P, and atrazine. A full description with information for $\mathrm{K}$ and lime applications is given by Yost et al. (2017).

Runoff Quantity and Quality Data. Measurement of runoff stage and discharge over a 3:1 broad-crested v-notch weir constructed at the outlet of the field has been described in detail by Baffaut et al. (2015). The vertical wall of the weir extends to $1 \mathrm{~m}$ belowground such that the structure captured all surface runoff and the shallow subsurface lateral flow from the field. While the field total area was 36 ha, the drainage area at the weir was limited to 31.6 ha (Mudgal et al. 2012) and included 12.5 ha of zone C (41\% of drainage area) and 19.1 ha of zones $\mathrm{A}$ and B (59\% of drainage area). Baffaut et al. (2013), Lerch et al. (2015b, 2015c), and Mudgal et al. (2012) have described the equipment used to collect automated flow proportioned runoff samples; the laboratory analysis methods used to determine sediment, nutrient, and herbicide concentrations; and the data processing methods to calculate daily loads. While there were some changes in equipment over the 22 years, the sampling regime (discharge to trigger sampling and sampling flow interval) remained the same over the whole period.

Data Analysis. The comparison of environmental outcomes during the conventional and PAS periods relied on statistical methods based on daily edge-of-field runoff and export of sediment, atrazine, and nutrients $\left(\mathrm{NO}_{3}-\mathrm{N}\right.$, ammonium-N $\left[\mathrm{NH}_{4}-\mathrm{N}\right]$, and dissolved P). Daily discharge (expressed as a depth over the drainage area) and constituent loads obtained during the conventional and PAS periods were compared based on (1) average annual totals expressed as a fraction of applied amounts, (2) flow and load duration curves, and (3) cumulative distribution functions. Annual mean, median, and standard deviation of daily precipitation, flow, and loads were calculated for each management system. For atrazine, the analysis used years when atrazine was applied and measured: odd years from 1993 to 2001 and 2005 to 2013 for the conventional and PAS systems, respectively. The year 2003 was excluded because atrazine was applied but inadvertently not analyzed in the water samples during that transition year. For other variables, all years were used. Losses were also calculated as a fraction of applied amounts. If the application was not annual, losses and applied amounts were aggregated over the relevant number of years. For $\mathrm{N}$, we combined the $\mathrm{NO}_{3}-\mathrm{N}$ and $\mathrm{NH}_{4}-\mathrm{N}$ losses in order to make the relative comparison with total $\mathrm{N}$ inputs. No statistical test was applied since annual values do not represent a true replication of the system. Average annual values determined the direction and magnitude of the change.

Flow duration curves relate daily flow value to their frequency of exceedance, also known as the flow duration interval. After ranking daily flow values in decreasing order, each value was assigned a frequency calculated with the Cunnane (1978) formula (equation 1):

$$
p_{k}=1-\frac{k-0.4}{N+0.2}
$$

where $p_{k}$ is the frequency of exceedance (i.e., the frequency at which a daily value exceeds this value), $k$ is the rank of the daily value, and $N$ is the total number of days in the data set. With $k$ varying from 1 to $N, p_{k}$ varies between 0 and 1 . The load duration curve is the plot of daily constituent loads as a function of the flow duration interval of the corresponding daily flow value. To determine if a water quality change had occurred as a result of the management, we applied a variant of the quantile-quantile plot method proposed by Spooner et al. (1985) where concentration data are ranked, and mean concentrations are calculated for each percentile for both periods and plotted against each other. The regression slope is then compared to one. In this study, availability of continuous discharge and flow weighted concentration data allowed a similar analysis based on daily loads. Median loads calculated for each percentile of flow duration interval for the two periods were plotted against each other, and the regression slope statistically compared relative to one. The method requires a similar range of flows during the before and after treatment periods, and this condition was met as well (see below).

Cumulative distribution functions (CDF) relate daily values to the frequency at which the variable (flow or load) was less or equal to that value. Although similar to the flow or load duration curve, the CDF considers the frequency of the daily load value directly, not the frequency of the corresponding flow value. Cumulative distribution functions were statistically compared using the nonparametric Kolmogorov-Smirnov test using the NPAR1WAY Procedure of SAS (SAS Institute 2011) at $p \leq 0.05$ for daily precipitation, daily flow, and daily $\mathrm{NO}_{3}-\mathrm{N}, \mathrm{NH}_{4}-\mathrm{N}$, dissolved P, and sediment loads using 1993 to 2003 data for the conventional period, and 2004 to 2014 for the PAS period. For atrazine, the test was based on only the years where atrazine was applied and analyzed in the runoff samples: odd years from 1993 to 2001 for the conventional period, and odd years from 2005 to 2013 for the PAS period.

Adjacent Replicated Plots. Thirty large plots $(20 \times 200 \mathrm{~m})$ adjacent to the field under study were established in 1991. Replicated management systems including the conventional system in this study, a no-till corn-soybean system, and a no-till corn-soybean-wheat with cover crops were consistently implemented from 1996 to 2010 , with each phase of the rotation replicated three times each year. Runoff and water quality were monitored in the corn phase of the rotation from 1997 to 2002 on two of the three replicates. No management replicated the PAS because it was specifically designed for the field and included multiple zones, which was not feasible on plots. Data from these plots were analyzed for runoff (Baffaut et al. 2015) and herbicide losses (Ghidey et al. 2005). In 2008, a soil quality assessment was conducted (Veum et al. 2015) using soil samples collected from 0 to 5 and 5 to $15 \mathrm{~cm}$ depth layers across three landscape positions (summit, backslope, and toeslope) to contrast the conventional system and the no-till corn-soybean-wheat rotation with cover crops. In addition, long-term effects of these cropping systems were estimated using model simulation (Baffaut et al. 2019). The conclusions of these analyses were used as needed to explain the differences in water quality from the field under study during the conventional and PAS periods.

\section{Results and Discussion}

Average Annual Values. Precipitation did not change appreciably over the two periods (table 3). The number of years under each management (11) was sufficiently long that each period included normal, wet, and dry years. Average annual precipitation varied by only $4 \%$ between the two periods. The driest summer during the conventional period was 1999 (74 mm) and the wettest was 1993 


\section{Table 3}

Average annual flow, herbicide, nutrient, and sediment export under the conventional (CONV) and precision agriculture (PAS) systems.

\begin{tabular}{|c|c|c|c|c|c|c|}
\hline \multirow[b]{3}{*}{ Variable } & \multicolumn{6}{|c|}{ Average annual value (coefficient of variation [\%]) } \\
\hline & \multicolumn{2}{|l|}{ Inputs } & \multicolumn{2}{|l|}{ Outputs } & \multicolumn{2}{|l|}{ Loss (\%) } \\
\hline & CONV & PAS & CONV & PAS & CONV & PAS \\
\hline Discharge (mm depth over drainage area) & & & $259(51)$ & $291(61)$ & $25(38)$ & $26(38)$ \\
\hline Atrazine (kg) & $68(10)$ & $25(18)$ & $1.1(43)$ & $0.7(26)$ & $2(52)$ & $3(41)$ \\
\hline Sediment $\left(\mathrm{kg} \mathrm{ha}^{-1}\right)$ & - & - & $4,768(91)$ & $608(178)$ & - & - \\
\hline Sediment without year $2007\left(\mathrm{~kg} \mathrm{ha}^{-1}\right)$ & - & - & $4,768(91)$ & $285(59)$ & - & - \\
\hline
\end{tabular}

(654 mm). During PAS, the driest summer was 2001 (113 mm); the wettest was 2008 (785 mm). The wettest springs occurred in 1995 (568 mm) and 2010 (469 mm). The most important differences in seasonal precipitation between the two periods were obtained for summer (15\% difference) and fall $(14 \%)$ with the PAS period experiencing more precipitation than the conventional period during these two seasons. Similar to precipitation, annual runoff volumes were similar over the two periods.

Sediment losses under the PAS were reduced by $87 \%$, despite including the high sediment losses caused by waterway grading in August of 2007. In that year, losses (3,830 $\mathrm{kg} \mathrm{ha}^{-1}$ ) were seven times the next highest annual sediment loss $\left(546 \mathrm{~kg} \mathrm{ha}^{-1}\right)$ during the PAS period. No-till combined with cover crops at all times reduced soil movement to very small amounts. If we exclude 2007, the average annual soil loss during the PAS period was $285 \mathrm{~kg} \mathrm{ha}^{-1}$, or only $6 \%$ of the average annual loss during the conventional period.

There was $\sim 60 \%$ less atrazine applied to the field during the PAS because corn was only grown in $40 \%$ of the field. These lower quantities translated to $40 \%$ less atrazine transported with runoff. As a result, loss as a function of applied was greater during the PAS period (2.7\% compared to $1.7 \%$; table 3 ).

Applied P increased under the PAS. Fertilization was informed by soil $\mathrm{P}$ tests, which showed excess at the boundary between zones $\mathrm{C}$ and $\mathrm{A}$, and deficiencies in the area just upstream of the weir. During most years of the PAS, fertilizer P applications were designed to increase soil $\mathrm{P}$ to support the growth of two crops and a cover crop annually. As a result, $\mathrm{P}$ applications almost tripled (2.8 ratio) during the PAS period and were especially large in the area closest to the weir. The P fertilization timing was quite different with some $\mathrm{P}$ applied each year under the PAS period compared to every other year under the conventional system. The increase of applied P led to a tripling of $\mathrm{P}$ (3.6 ratio) transported by runoff. However, the ratios of lost $\mathrm{P}$ to applied $\mathrm{P}$ remained similar between the two systems, at $5 \%$ and $6 \%$ of applied during the conventional and PAS periods, respectively.

Under PAS, $\mathrm{N}$ was applied on corn and wheat at planting and in-season with variable rates. In-season variable $\mathrm{N}$ applications resulted in 50 to $110 \mathrm{~kg} \mathrm{~N} \mathrm{ha}$ applied on wheat and 0 to $235 \mathrm{~kg} \mathrm{~N} \mathrm{ha}{ }^{-1}$ on corn. Average total $\mathrm{N}$ applied over the whole areas ranged from 160 to $200 \mathrm{~kg} \mathrm{~N} \mathrm{ha}^{-1}$ for corn and 107 to $129 \mathrm{~kg} \mathrm{~N} \mathrm{ha}^{-1}$ for wheat. In addition, uniform rates of 18 to $70 \mathrm{~kg} \mathrm{~N} \mathrm{ha}{ }^{-1}$ were applied to cover crops because it was included in the DAP or MAP used for P fertilization. Overall, total $\mathrm{N}$ applied was almost the same ( $1 \%$ difference) during the two periods. However, the application timing was more spread out during the growing seasons of the various crops grown under PAS. In spite of equal amounts of applied $\mathrm{N}$, average annual $\mathrm{N}$ losses under PAS were 39\% lower than those under the conventional system. The $\mathrm{N}$ lost in runoff as a fraction of applied $\mathrm{N}$ was reduced by close to $44 \%$ (table 3 ).

Flow Duration Curves and Cumulative Distribution Functions. Figure 3 shows the flow duration curves and load duration curves for sediment, atrazine, dissolved $\mathrm{P}$, and $\mathrm{N}$. These curves and the regression slopes between median loads for each flow duration interval (figure 4) highlight the impact of PAS on a daily basis. Precipitation duration curves are not shown but were identical.

The range of daily flow values can be divided into two parts. For flow volumes $>1$ $\mathrm{mm} \mathrm{d}^{-1}$ over the drainage area, the two flow duration curves appear identical. However, the quantile-quantile plot showed greater flow during PAS than during the conventional period for high runoff events, and the regression slope of the quantile-quantile plot was significantly greater than 1 (table 4). This corresponded to when surface runoff on nearly saturated soil was the dominant process (high runoff events). Low daily runoff volumes $(<1$ $\mathrm{mm} \mathrm{d}^{-1}$ ) were more frequent under PAS than during the conventional period. The accumulated flow volume when daily flow $<1 \mathrm{~mm} \mathrm{~d}^{-1}$ represented only $3 \%$ of the annual flow volume during either period. However, this happened during $78 \%$ of the non-zero flow days, i.e., very frequently. In spite of this, the KolmogorovSmirnov test showed no significant difference between the two flow CDF (table 4).

Comparing loads for the same flow interval between the two systems clearly shows that daily $\mathrm{NO}_{3}$ and sediment loads decreased (slope significantly less than 1) as a result of PAS, which was confirmed by the KolmogorovSmirnov tests. Given the similarity of flows during the two periods, decreasing sediment and $\mathrm{NO}_{3}-\mathrm{N}$ loads were clear benefits of the PAS for these two constituents, decreasing concentrations and loads. On the other hand, results for $\mathrm{NH}_{4}-\mathrm{N}$ were inconclusive. The regression slope of the quantile-quantile plot indicates an increase of $\mathrm{NH}_{4}-\mathrm{N}$ transport, but the Kolmogorov-Smirnov test did not indicate any difference. Results were similarly inconclusive for atrazine, with the slope indicating a decrease of daily loads while no significant difference was detected between the two CDF. As we have seen previously, dissolved $\mathrm{P}$ loads increased but the increases were explained by increased inputs.

Effect of Management on Discharge. This analysis confirmed previous analyses of runoff volumes under tilled and no-till systems. Using data from the adjacent plots, Ghidey et al. (2005) showed no difference in growing season runoff volume from the conventional system and a no-till corn-soybean system. Similarly, analysis of event data from these large plots 


\section{Figure 3}

Flow for (b) sediment, (c) atrazine, (d) dissolved phosphorus, (e) nitrate-nitrogen, and (f) ammonium-nitrogen, and median load duration curves (a) under the conventional (CONV) and precision agriculture systems (PAS). The area used to normalize the constituent load is the total drainage area.

(a)

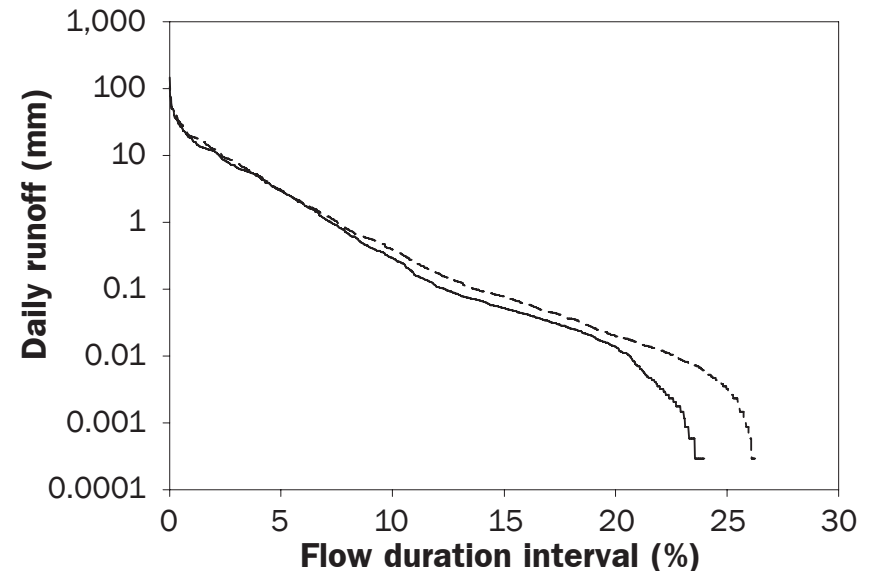

(c)

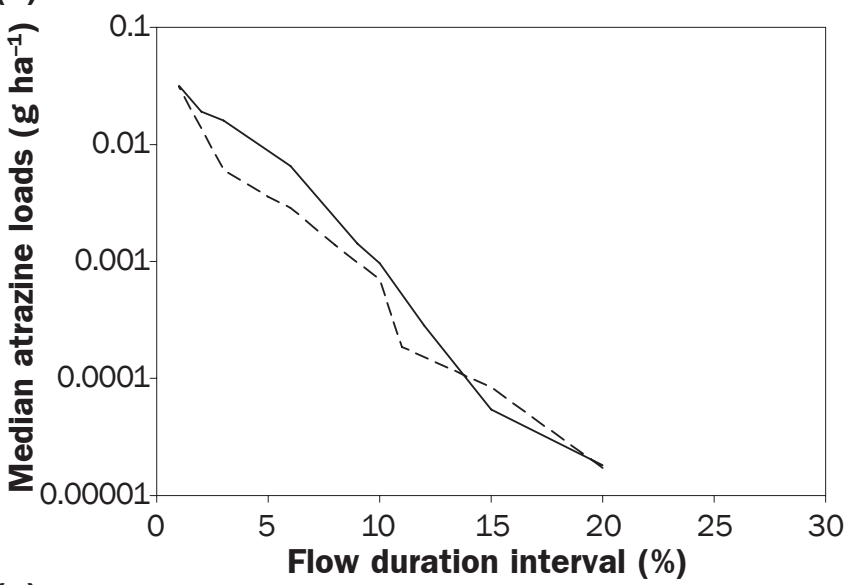

(e)

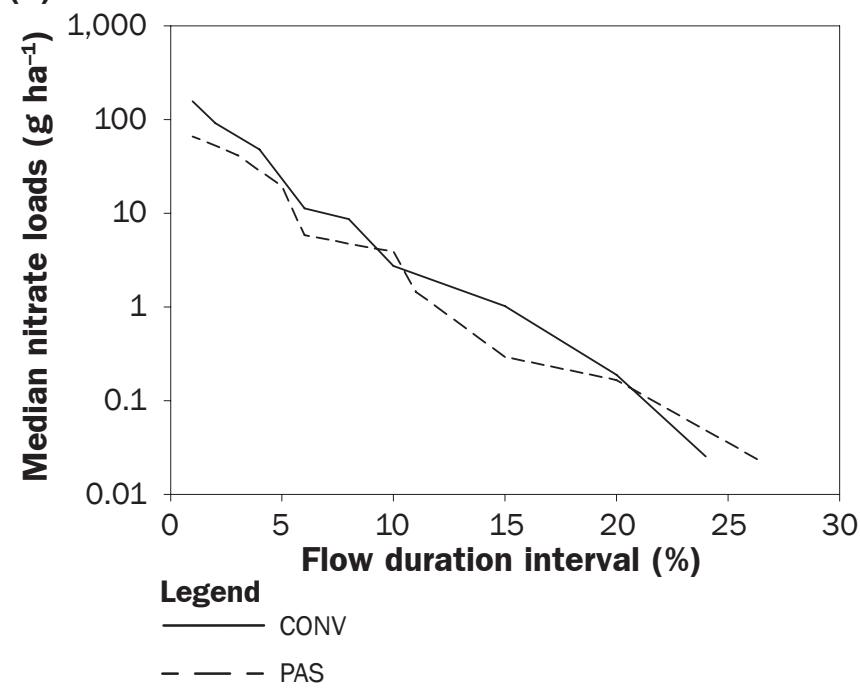

(b)

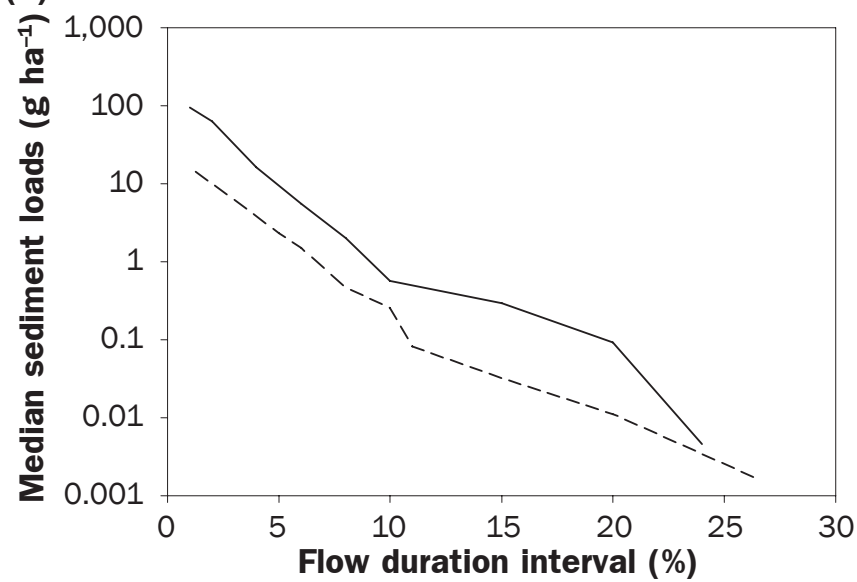

(d)

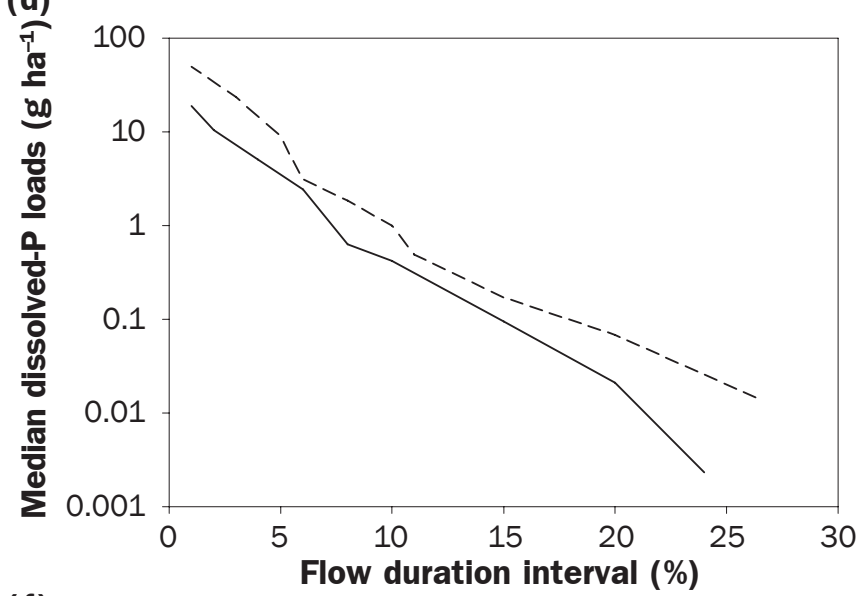

(f)

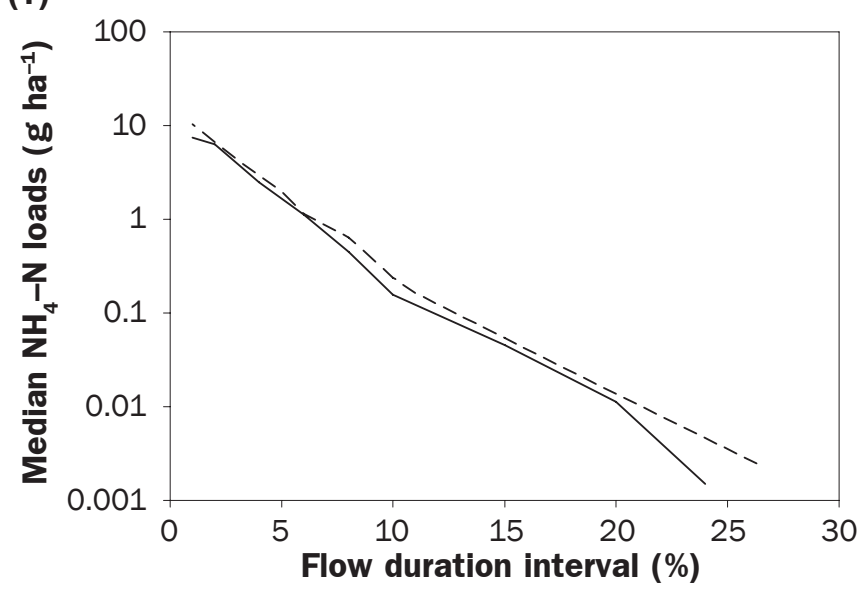

confirmed no difference between tilled and no-till cropping systems, with or without cover crops (Baffaut et al. 2015). Field-scale data did show some differences in discharge between this field during the conventional period and other fields with no-till management systems. However, different bio-physical characteristics of the fields (i.e., slope, slope length, and depth to clay) and differences in management prior to the experiment may have affected the results
(Baffaut et al. 2015). In this study, the field was the same over the two periods, and the management prior to the conventional management period, which had been in place since 1981, was similar to the conventional man- 


\section{Figure 4}

Quantile-Quantile plots of (a) daily flow and (b through f) loads for the conventional and precision agriculture systems. The area used to normalize the constituent load is the total drainage area, independent of the area treated or fertilized.

(a)

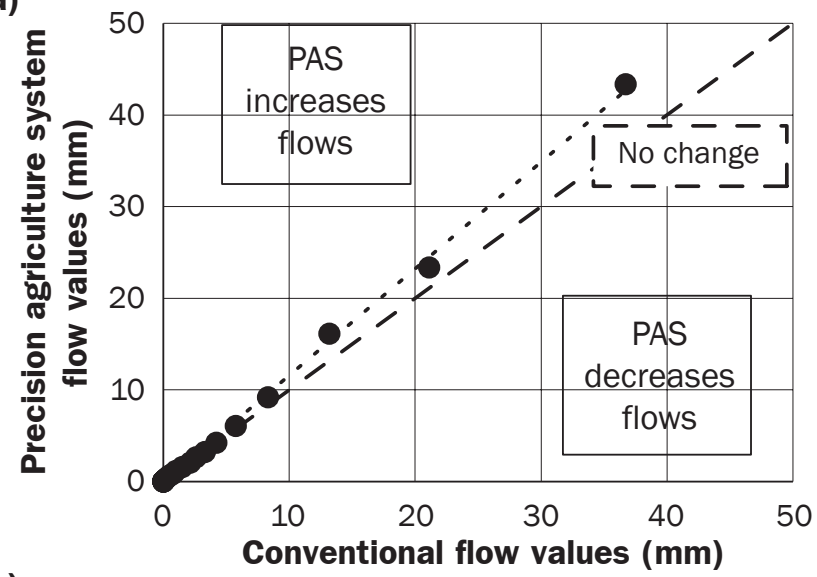

(c)

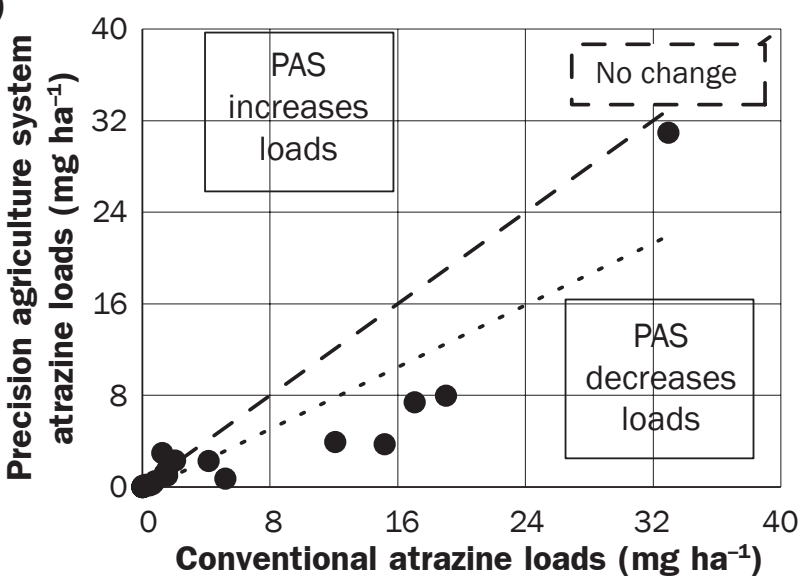

(e)

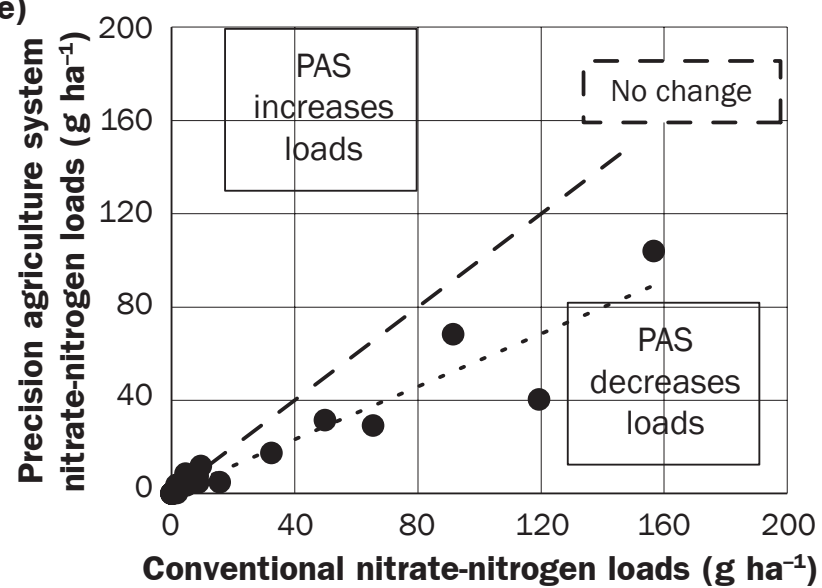

(b)

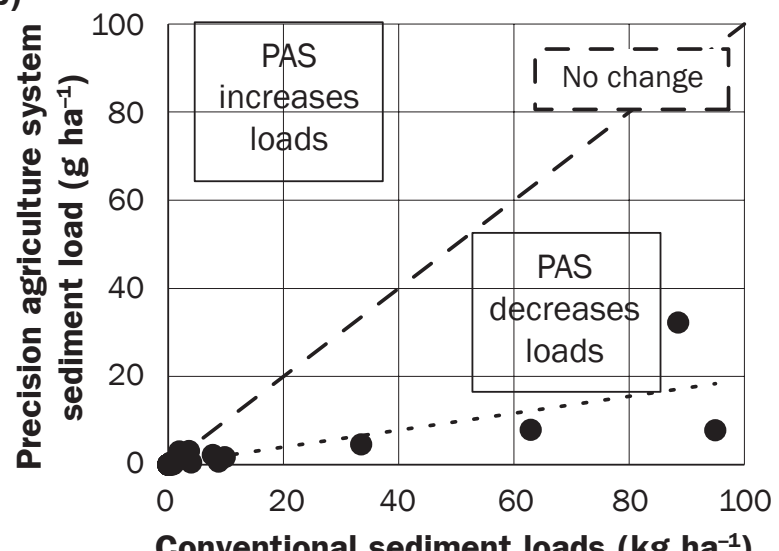

(d)

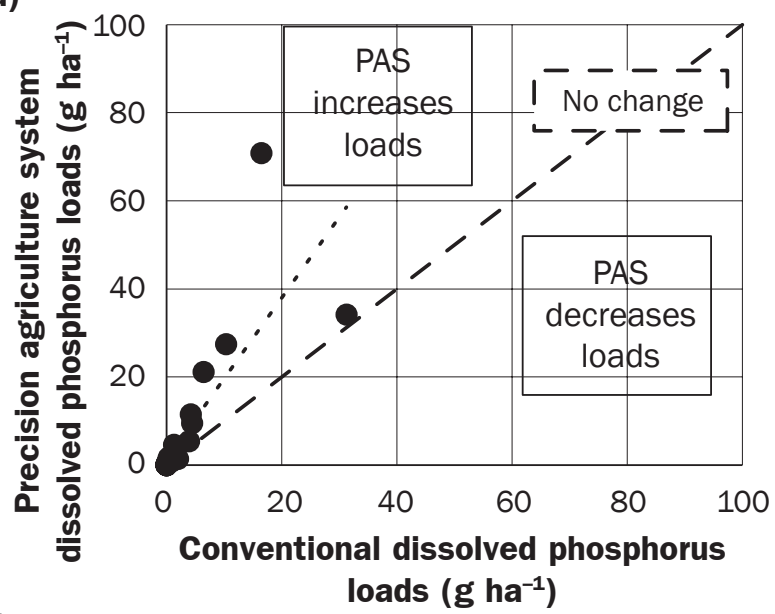

(f)

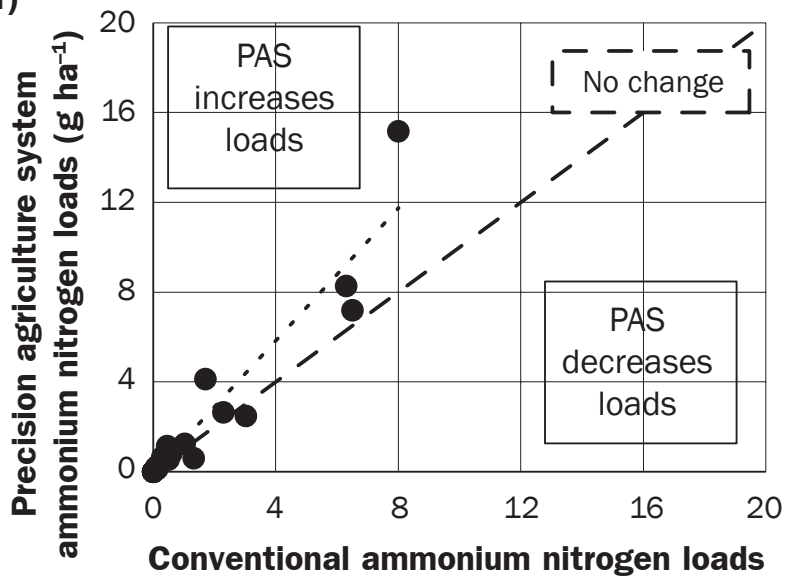

$\left(\mathrm{g} \mathrm{ha}^{-1}\right)$ agement: soybean, grain sorghum, and wheat production under disc and cultivator tillage with inorganic fertilizers (Lerch et al. 2005). Thus, initial conditions at the beginning of the conventional and PAS periods were likely to be similar. While full soil characterization was not repeated in 2003, 1993 and 2003 field mean levels of $\mathrm{P}\left(29\right.$ and $31 \mathrm{~kg} \mathrm{P}$ pentoxide $\left[\mathrm{P}_{2} \mathrm{O}_{5}\right]$ $\mathrm{ha}^{-1}$, respectively), $\mathrm{K}$ (189 and $158 \mathrm{~kg} \mathrm{~K}_{2} \mathrm{O} \mathrm{ha}^{-1}$, respectively), and $\mathrm{pH}$ (6.1 and 6.3, respectively) confirm this assumption.
The increased frequency of daily runoff volumes $<1 \mathrm{~mm} \mathrm{~d}^{-1}$ suggests that soil water content was greater during that period and led to excess water moving as subsurface flow resurfacing before getting to the field outlet, or captured by the foundation of the 


\section{Table 4}

Differences in daily precipitation, flow, and load distributions as indicated by the regression slopes of the quantile-quantile plots and the Kolmogorov-Smirnov test on cumulative distribution functions of daily values.

\begin{tabular}{lllllll}
\hline Variable & \multicolumn{2}{l}{$\mathbf{9 5}$ confidence interval of the slope } & & & & \\
\cline { 2 - 3 } & Minimum & Maximum & $\boldsymbol{r}^{\mathbf{2}}$ & Slope value relative to 1 & Kolmogorov-Smirnov test \\
\hline Precipitation & 1.07 & 1.13 & 0.995 & Significantly greater & Not different \\
Flow & 1.15 & 1.18 & 0.998 & Significantly greater & Not different \\
Sediment loads & 0.14 & 0.24 & 0.656 & Significantly smaller & Significantly different \\
Atrazine loads & 0.56 & 0.79 & 0.814 & Significantly smaller & Not different \\
Dissolved P loads & 1.38 & 2.31 & 0.649 & Significantly greater & Significantly different \\
$\mathrm{NO}_{3}-\mathrm{N}$ loads & 0.51 & 0.63 & 0.913 & Significantly smaller & Significantly different \\
$\mathrm{NH}_{4}-\mathrm{N}$ loads & 1.32 & 1.63 & 0.916 & Significantly greater & Not different \\
\hline
\end{tabular}

Notes: $\mathrm{P}=$ phosphorus. $\mathrm{NO}_{3}-\mathrm{N}=$ nitrate-nitrogen. $\mathrm{NH}_{4}-\mathrm{N}=$ ammonium-nitrogen.

weir. This result could indicate greater water holding capacity in the topsoil layer under PAS. However, studies on the plots adjacent to this field did not detect any significant differences in hydraulic conductivity in tilled and no-till systems (Jiang et al. 2007; Jung et al. 2007), or macroaggregate stability and bulk density (Veum et al. 2015). Similarly, Haruna et al. (2018) have detected no significant differences in bulk density or water holding capacity of the topsoil layer $(20 \mathrm{~cm})$ between tilled and no-till systems with and without cover crops on a somewhat poorly drained soil. Thus, the increase of interflow remains unexplained by supporting experiments and analyses. One possibility is that PAS did increase the duration of runoff events, suggesting that runoff velocity was reduced. Analysis of hydrograph dynamics has not been completed at this time.

Effect of Management on Sediment Loss. The quantitatively largest impact of PAS on surface runoff water quality was the sharp reduction in sediment transport. Average annual losses were reduced by $87 \%$ (95\% if we exclude 2007; table 3), and daily loads for similar discharge were reduced by $50 \%$ to $90 \%$. These data demonstrated that no-till in combination with cover crops was very effective at reducing soil erosion on these soils. While no-till alone is very effective at reducing sediment losses (Verbree et al. 2010; Zeimen et al. 2006), our own observations on adjacent no-till corn-soybean plots over the 1991 to 2009 period showed that when no-till was implemented without cover crops, rills formed in the area of concentrated flow. These rills then increased in size with subsequent years unless they were flattened by localized tillage. Cover crops provided greater stability to the soil and prevented these rills from occurring. This is consistent with results from replicated plots on claypan soils by $\mathrm{Zhu}$ et al. (1989), who showed that cover crops were a critical aspect for a successful no-till soybean crop when implemented on claypan soils: cover crops reduced soil loss from plots by $85 \%$ to $90 \%$ compared to the same no-till system without cover crops.

Effect of Management on Herbicide Loss. Water quality data from the adjacent replicated plots showed that atrazine losses were two to three times greater under the no-till corn-soybean system than when the chemical was incorporated into the soil by tillage (Ghidey et al. 2005). A modeling study based on the same plots corroborated the finding over a 14-year long simulation period (Baffaut et al. 2019). The result was confirmed at field scale by contrasting losses from this field under conventional management to a field under no-till corn-soybean during a subset of the conventional period (1997 to 2001). Lerch et al. (2013) also reported significantly greater atrazine losses in runoff from a claypan soil when comparing a no-till system to two tilled treatments in which atrazine was incorporated. Thus we expected treated area atrazine losses to be two to three times as high as during the conventional period. During PAS, the treated area was $40 \%$ of the field. The overall total applied amount was $37 \%$ of what had been applied during the conventional period because of varying application rates from year to year as a result of the split application. Based on these inputs and the conclusions derived from these previous studies, we expected losses to be $74 \%$ to $111 \%$ of what was lost during the conventional period. Yet, average annual losses were only $\sim 60 \%$ and daily losses were $56 \%$ to $79 \%$ of those under the conventional system (table 4). Expressed as a fraction of applied, losses were only $60 \%$ greater $(2.7 \%$ versus $1.7 \%$; table 3 and figures 3 and 4) as opposed to $100 \%$ to $200 \%$ as expected from previous studies. Overall, the no-till PAS did not increase atrazine losses in runoff as much as expected.

One reason was the placement of atrazine on the far end of the field (zone C), relative to the monitoring weir. Under the zone management approach used, the remainder of the field was in wheat (zones A and B) during the vulnerable atrazine transport period from April through June (Lerch et al. 2011b). Thus, atrazine had to move from the south end of the field, by either surface runoff or interflow, through the growing wheat, which functioned as an effective vegetative buffer strip that retained atrazine in the field. Further, the wheat area was greater than that of the corn, creating a source-to-buffer-area ratio of $<1: 1$. On claypan soils, grass buffers are estimated to reduce atrazine transport by $15 \%$ to $21 \%$ at source-to-buffer-area ratios up to 20:1 (Lerch et al. 2017) through a combination of runoff infiltration and herbicide adsorption (to plant residues and surface soil). In that study, the role of adsorption was greater than infiltration, demonstrating that vegetative buffers are effective for poorly drained soils with limited infiltration or when saturated. Since PAS did not decrease runoff on an annual basis compared to the conventional system, increased infiltration may have been limited as a retention mechanism. However, if the PAS did indeed reduce runoff velocity (figure 3 ; runoff flow duration curves), this allowed more time for atrazine to interact with crop residues and surface soil, presumably leading to greater atrazine adsorption and retention in the field compared to that previously observed for conventional no-till systems (i.e., corn grown on whole field or plot).

Once retained in the wheat, the atrazine may have also degraded faster in the soil. Grasses have been shown to increase atrazine degradation in the rhizosphere by a combination of stimulated microbial activity and production of 
atrazine degrading phytochemicals (Willett et al. 2016). Members of the Poacea family, which includes wheat, have been documented to produce benzoxazinone compounds that can nonenzymatically degrade atrazine (Niemeyer 2009; Willett et al. 2016). Long-term atrazine usage on this field may have also resulted in microbial adaptation and accelerated atrazine degradation in soil over time as has been widely documented (Krutz et al. 2010; Lerch et al. 2017). The 2008 soil assessment (Veum et al. 2015) showed that no-till and cover crops increased microbial biomass carbon (C) by $64 \%$. Microbial biomass $\mathrm{C}$ represents an estimate of the microbial population that is available to decompose residues and organic compounds (Vance et al. 1987). The process of adaptation occurs quickly (Zablotowicz et al. 2007), and atrazine half-life in soil can decrease from 60 to 120 days in nonadapted soil to 1 to 12 days in adapted soil (Krutz et al. 2010; Lerch et al. 2017). Atrazine has been applied to this field 11 times since 1993, and microbial adaptation and accelerated degradation in this field are probable.

Finally, there also might have been greater adsorption of atrazine to soil caused by the increased soil organic C content of the topsoil layer under PAS. The 2008 soil assessment (Veum et al. 2015) showed that no-till and cover crops increased organic $\mathrm{C}$ in the top 5 $\mathrm{cm}$ of soil by $60 \%$. Soil organic matter at the soil surface does increase adsorption of atrazine to soil particles (Ben-Hur et al. 2003), and decrease its ability to move with surface runoff.

Effect of Management on Phosphorus Loss. Many studies report greater dissolved $\mathrm{P}$ losses from no-till grain systems compared to tilled ones because the fertilizer remains available on the soil surface instead of being incorporated by tillage: Smith et al. (2015) reported growing season losses 2 to 4.5 times those from tilled systems, and Verbree et al. (2010) reported losses 2 to 9 times greater for no-till. With little reduction of runoff on claypan soils, not incorporating $\mathrm{P}$ only increases the amount picked up by runoff (Zeimen et al.2006). Modeling results on the plots adjacent to this field showed that no-till would double dissolved $\mathrm{P}$ losses (Baffaut et al. 2019). As we have seen before, PAS resulted in 2.8 times as much $\mathrm{P}$ applied than during the conventional period. Based on published studies and with almost 3 times as much $\mathrm{P}$ applied, we expected the losses to increase by as much as a factor of 6 . Yet, annual dissolved $\mathrm{P}$ losses increased by a ratio of only
3.6 (an increase comparable to the increase in inputs), and daily losses for similar discharge increased by $38 \%$ to $131 \%$.

Phosphorus applications during the PAS period were spread out during the year instead of being coordinated with planting operations in April or May, just ahead of the period with the highest risk for runoff. While some $\mathrm{P}$ was still applied in April or May from 2004 to 2014 with the starter fertilizer, buildup applications were scheduled in October after corn or soybean harvest, when the ground was clear and runoff less likely. In 2005, an October application was not feasible and it occurred in February of 2006. Risk of P runoff losses is greatest immediately after application (Smith et al. 2018). For three of the four conventional period $\mathrm{P}$ applications, runoff occurred within one week of $\mathrm{P}$ application. The fourth one was followed by a $90 \mathrm{~mm}$ event nine days after application. In contrast, no runoff event occurred within one week of any of the fall or winter P applications during the PAS period. Some did follow the spring applications, but the applied amounts were much smaller. Fall and winter $\mathrm{P}$ applications are problematic in regions where soils may freeze, which includes Missouri. Frozen conditions were considered in scheduling the February application, and soil temperatures were always $>0^{\circ} \mathrm{C}$. In Missouri, the long, warm, and dry autumns provide opportunities for $\mathrm{P}$ buildup at a time of minimal risk of runoff. In addition, the presence of growing wheat and cover crops increased evapotranspiration and $\mathrm{P}$ uptake and further decreased the likelihood of $\mathrm{P}$ loss with runoff. This helped explain identical P loss as a fraction of applied in spite of not incorporating the fertilizer.

The increased $\mathrm{P}$ sorption to soil may also explain the lower than expected P losses. In the 2008 soil quality assessment (Veum et al. 2015), the no-till system with cover crops resulted in increased soil organic $\mathrm{C}$, which increases the affinity of $\mathrm{P}$ to soil particles similarly to herbicides. Indeed, the same soil quality assessment found 33\% less extractable $\mathrm{P}$ under the no-till system with cover crops than under the conventional system.

Effect of Management on Nitrogen Loss. Applied UAN consists of 50\% urea, $25 \% \mathrm{NH}_{4}^{-}$ $\mathrm{N}$, and $25 \% \mathrm{NO}_{3}-\mathrm{N}$. Ammonium-N typically does not remain in the soil very long because of the nitrification and volatilization processes. Additionally, when soil water content is near saturation, denitrification can occur. During the PAS period, $\mathrm{NO}_{3}-\mathrm{N}$ daily losses in run- off were significantly smaller (about half) than the losses observed during the conventional period (table 4). Ammonium-N losses in runoff were greater during the PAS period than during the conventional period according to the quantile-quantile plots. The KolmogorovSmirnov test showed no significant change. Zhu et al. (1989) also found less $\mathrm{NO}_{3}-\mathrm{N}$ and more $\mathrm{NH}_{4}-\mathrm{N}$ in surface runoff when comparing losses from a soybean field with and without cover crops. As in this study, the field was underlain by a soil with a claypan within its profile.

All $\mathrm{N}$ transformation processes (nitrification, volatilization, denitrification, and immobilization) were likely taking place, but in varying degrees during both management periods. These processes largely are governed by timing, amount, placement, and source of $\mathrm{N}$ fertilization; $\mathrm{C}: \mathrm{N}$ ratio of plant residues and the degree of incorporation of these residues into the soil; and soil water and its impact on soil oxygen $(\mathrm{O})$. Aspects of all these processes were different between the two management systems contrasted in this investigation. As seen previously, the higher frequency of low flow days $\left(<1 \mathrm{~mm} \mathrm{~d}^{-1}\right)$ under PAS suggests that soil water content was greater during that period. Anaerobic conditions may have been more frequent, which, among other things, prevent nitrification and promote denitrification. With less nitrification, more $\mathrm{NH}_{4}-\mathrm{N}$ and less $\mathrm{NO}_{3}-\mathrm{N}$ was available for transport by surface runoff and subsurface flow.

In addition, during the conventional period, $\mathrm{N}$ fertilizer was applied in April at planting, a period that is near the beginning of the high runoff period (April to June). Thus, there is high potential for loss of $\mathrm{N}$ with runoff and subsurface flow. During PAS, some $\mathrm{N}$ was applied in April, but less. The side-dress application occurred in June, when plants are waist high and dewater the soil profile more effectively, and precipitation events start to decrease in magnitude and frequency. The timing of the $\mathrm{N}$ application may have contributed to overall lower losses of $\mathrm{NO}_{3}-\mathrm{N}$ during the PAS period.

Cover crops may also have had an effect on the availability of $\mathrm{N}$ in the soil profile. Farm managers use cover crops in part because these crops can capture excess $\mathrm{N}$ remaining in the soil when grown following a harvested cash crop, and immobilize it in their biomass when it would otherwise leach through the soil. That $\mathrm{N}$ is then released when the cover crops are 
killed. Thus cover crops reduce the availability of $\mathrm{NO}_{3}$ in the soil profile and the likelihood of transport by surface and subsurface flow.

Toward an Improved Management System. The PAS showed significant benefits in terms of reduced sediment and $\mathrm{NO}_{3}$ losses in runoff. Anticipated trade-offs between sediment reductions and increases in atrazine and dissolved P were not observed. One challenge with PAS was the increasingly difficult management of weeds where soybean and wheat were grown, because of herbicide resistance of weeds like amaranth (Amaranthus palmeri). The problem did not occur where corn was grown because atrazine was applied every other year. The zonal management also complicated the organization and timing of field operations. A solution may be to switch to a three-year no-till corn-soybean-wheat with cover crops, variable rates of fertilizers, and split applications of atrazine. This aspirational system would combine the advantages of single crops across the whole field with the ability to apply atrazine once every three years to manage weed resistance.

Without the presence of a large area in wheat to trap and decay atrazine and its derivatives, atrazine losses may increase. To avoid this possibility, a rotary harrow could be used to incorporate the chemical into the first $5 \mathrm{~cm}$ of soil without significantly disturbing the residue cover. Lerch et al. (2013) showed that such incorporation can significantly reduce herbicide losses compared to a no-till system, without significantly increasing soil losses. Such a compromise could be beneficial for other chemicals as well: other herbicides and $\mathrm{P}$ fertilizer in particular. In addition, a vegetated buffer placed at the outlet of the field could further reduce sediment-bound and dissolved herbicides by trapping sediment, increasing infiltration, and increasing adsorption of the chemicals. A source-to-buffer-area ratio of 20:1 would amount to 1.6 ha of perennial grasses at the bottom of the field.

In this study, all but the starter $\mathrm{N}$ fertilizer was surface applied, and a stabilizer was added to control volatilization of urea. Plant uptake could only occur after precipitation and infiltration moved $\mathrm{N}$ into the root zone. However, precipitation also increased the risk of loss by runoff. Subsurface placement of $\mathrm{N}$ at planting and in season would decrease the potential for volatilization and transport by runoff, and make the fertilizer readily available to the plants. This would require appropriate equipment for doing so, especially in-season when plants are knee high or taller. Costs will certainly affect this decision.

\section{Summary and Conclusions}

After 11 years of conventional management in a 36 ha field, productivity data led to the definition of two main management zones: wheat and soybean in $60 \%$ of the field, and corn and soybean in the remaining $40 \%$. Additionally the system included no-till, cover crops, atrazine split-applications based on weed pressure, variable $\mathrm{N}$ rates, and variable rates of fall-applied P. As expected, the system resulted in greatly reduced sediment losses (87\% less). While plot-scale experimental and modeling studies suggested that no-till would result in increased herbicide and dissolved $\mathrm{P}$ losses, the assessment showed lower losses than expected. Overall $\mathrm{N}$ losses decreased by $40 \%$ but $\mathrm{NO}_{3}-\mathrm{N}$ and $\mathrm{NH}_{4}-\mathrm{N}$ behaved differently: $\mathrm{NO}_{3}-\mathrm{N}$ losses decreased by $\sim 57 \%$ while $\mathrm{NH}_{4}-\mathrm{N}$ losses increased by $47 \%$. Conclusions from plot-scale experiments were consistent with these results: increased adsorption caused by gains in soil organic $\mathrm{C}$ at the soil surface resulting from no-till and cover crops, adaptations of microorganisms to atrazine, and the wheat area functioning as a buffer for herbicides applied at the top end of the field. Other not-specifically tested explanations included fertilizer applications when runoff risk was lower, and uptake of nutrients by the cover crops. These results demonstrate the benefits of a comprehensive conservation plan that includes multiple practices, some counteracting the negative aspects of others.

The results obtained during the 11 years of the PAS and the farming experience gained led to the proposal for an aspirational system: a three-year no-till corn-soybean-wheat with cover crops, variable rates of fertilizers, split applications of atrazine, incorporation of agrichemical inputs with a rotary harrow, 1.6 ha of perennial grasses at the bottom of the field functioning as a buffer, and subsurface $\mathrm{N}$ application. Some of these aspects have been implemented and future analyses will determine their benefits.

\section{Acknowledgements}

The authors sincerely thank numerous USDA and University of Missouri personnel for assisting in the establishment, maintenance, and management of the field used in this study, in the associated monitoring infrastructure, and in the collection and chemical analysis of water samples. We gratefully acknowledge that partial funding for this research was provided by the USDA Natural Resources Conservation Service Conservation Effects Assessment Project Watershed Assessment Studies and the USDA-CSREES (now National Institute for Food and Agriculture) National Integrated Water Quality Program-Conservation Effects Assessment Project (CEAP) (Grant no. 2005-51130-02380). This research was also supported by the USDA Agricultural Research Service (ARS) Long-Term Agroecosystem Research network, and ARS National Program 211.

\section{Disclaimer}

Mention of trade names or commercial products in this article is solely for the purpose of providing specific information and does not imply recommendation or endorsement by the USDA.

\section{References}

Baffaut, C., F. Ghidey, R.N. Lerch, N.R. Kitchen, K.A. Sudduth, and E.J. Sadler. 2019. Long-term simulated runoff and water quality from grain cropping systems on restrictive layer soils. Agricultural Water Management 213:36-48.

Baffaut, C., F. Ghidey, K.A. Sudduth, R.N. Lerch, and E.J. Sadler. 2013. Long-term suspended sediment transport in the Goodwater Creek Experimental Watershed and Salt River Basin, Missouri, USA. Water Resources Research 49.

Baffaut, C., E.J. Sadler, and F. Ghidey. 2015. Long-term agroecosystem research in the Central Mississippi River Basin: Goodwater Creek Experimental Watershed flow data. Journal of Environmental Quality 44(1):18-27.

Ben-Hur, M., J. Letey, W.J. Farmer, C.F. Williams, and S.D. Nelson. 2003. Soluble and solid organic matter effects on atrazine adsorption in cultivated soils. Soil Science Society of America Journal 67(4):1140-1146.

Blanchard,P.E., and R.N.Lerch.2000.Watershed vulnerability to losses of agricultural chemicals: Interactions of chemistry, hydrology, and land-use. Environmental Science and Technology 34(16):3315-3322.

Bosch, D.D., C.C. Truman, T.L. Potter, L.T. West, T.C. Strickland, and R.K. Hubbard. 2012. Tillage and slope position impact on field-scale hydrologic processes in the South Atlantic Coastal Plain. Agricultural Water Management 111:40-52.

Cunnane, C. 1978. Unbiased plotting position: A review. Journal of Hydrology 37:205-222.

Haruna, S.I., N.V. Nkongolo, S.H. Anderson, F. Eivazi, and S. Zaibon. 2018. In situ infiltration as influenced by cover crop and tillage management. Journal of Soil and Water Conservation 73(2):164-172, doi:10.2489/jswc.73.2.164.

Helmers, M.J., X. Zhou, H. Asbjornsen, R. Kolka, M.D. Tomer, and R.M. Cruse. 2012. Sediment removal by prairie filter strips in row-cropped ephemeral watersheds. Journal of Environmental Quality 41(5):1531-1539.

Jiang, P., S.H. Anderson, N.R. Kitchen, E.J. Sadler, and K.A. Sudduth. 2007. Landscape and conservation management effects on hydraulic properties of a 
claypan-soil toposequence. Soil Science Society of America Journal 71(3):803-811.

Jung, W.K., N.R. Kitchen, S.H. Anderson, and E.J. Sadler. 2007. Crop management effects on water infiltration for claypan soils. Journal of Soil and Water Conservation 62(1):55-63.

Kitchen, N.R., P.E. Blanchard, and R.N. Lerch. 2015. Long-Term agroecosystem research in the Central Mississippi River Basin: Hydrogeologic controls and crop management influence on nitrates in loess and fractured glacial till. Journal of Environmental Quality 44(1):58-70.

Kitchen, N.R., K.A. Sudduth, and S.T. Drummond. 1999. Electrical conductivity as a crop productivity measure for claypan soils. Journal Production Agriculture 12(4):607-617.

Kitchen, N.R., K.A. Sudduth, S.T. Drummond, P.C. Scharf, H.L. Palm, D.F. Roberts, and E.D. Vories. 2010. Ground-based canopy reflectance sensing for variablerate nitrogen corn fertilization. Agronomy Journal 102(1):71-84.

Kitchen, N.R., K.A. Sudduth, D.B. Myers, R.E. Massey, E.J. Sadler, R.N. Lerch, J.W. Hummel, and H.L. Palm. 2005. Development of a conservation-oriented precision agriculture system: Crop production assessment and plan implementation. Journal of Soil and Water Conservation 60(6):421-430.

Krutz, L.J., D.L. Shaner, and R.M. Zablotowicz. 2010. Enhanced degradation and soil depth effects on the fate of atrazine and major metabolites in Colorado and Mississippi soils. Journal of Environmental Quality 39:1369-1377

Lerch, R.N., C. Baffaut, N.R. Kitchen, and E.J. Sadler. 2015a. Long-term agro-ecosystem research in the Central Mississippi River Basin, USA-Dissolved nitrogen and phosphorus transport in a high runoff potential watershed. Journal of Environmental Quality 44:44-57.

Lerch, R.N., C. Baffaut, E.J. Sadler, and R.J. Kremer. 2015b. Long-term agroecosystem research in the Central Mississippi River Basin: Goodwater Creek Experimental Watershed and regional herbicide water quality data. Journal of Environmental Quality 44(1):28-36.

Lerch, R.N., C.M. Harbourt, R.R. Broz, and T.J. Thevary. 2013. Atrazine incorporation and soil erosion: Balancing competing water quality concerns for claypan soils. Transactions of the ASABE 56(6):1305-1316.

Lerch, R.N., N.R. Kitchen, C. Baffaut, and E.D. Vories. 2015c. Long-term agroecosystem research in the Central Mississippi River Basin: Goodwater Creek Experimental Watershed and regional nutrient water quality data. Journal of Environmental Quality 44(1):37-43.

Lerch, R.N., N.R. Kitchen, R.J. Kremer, W.W. Donald, E.E. Alberts, E.J. Sadler, K.A. Sudduth, D.B. Myers, and F. Ghidey. 2005. Development of a conservation-oriented precision agriculture system: Water and soil quality assessment. Journal of Soil and Water Conservation 60(6):411-421.

Lerch, R.N., C.H. Lin, K.W. Goyne, R.J. Kremer, and S.H. Anderson. 2017. Vegetative buffer strips for reducing herbicide transport in runoff: Effects of buffer width, vegetation, and season. Journal of the American Water Resources Association 53:667-683, doi:10.1111/1752-1688.12526.

Lerch, R.N., E.J. Sadler, C. Baffaut, N.R. Kitchen, and K.A Sudduth. 2011a. Herbicide Transport in Goodwater Creek Experimental Watershed: II. Long-term research on Acetochlor, Alachlor, Metolachlor, and Metribuzin. Journal of the American Water Resources Association 47(2):224-238.

Lerch, R.N., E.J. Sadler, K.A. Sudduth, C. Baffaut, and N.R. Kitchen. 2011b. Herbicide transport in Goodwater Creek Experimental Watershed: I. Long-term research on atrazine. Journal of the American Water Resources Association 47(2):209-223.

Mudgal, A., C. Baffaut, S.H. Anderson, E.J. Sadler, N.R. Kitchen, K.A. Sudduth, and R.N. Lerch. 2012. Using the Agricultural Policy/Environmental eXtender to develop and validate physically based indices for the delineation of critical management areas. Journal of Soil and Water Conservation 67(4):284-299, doi:10.2489/ jswc.67.4.284.

Niemeyer, H.M. 2009. Hydroxamic acids derived from 2-Hydroxy-2H-1,4-Benzoxazin-3(4H)-one: Key defense chemicals of cereals. Journal of Agricultural and Food Chemistry 57(5):1677-1696.

Peacher, R.D., R.N. Lerch, R.C. Schultz, C.D. Willett, and T.M. Isenhart. 2018. Factors controlling streambank erosion and phosphorus loss in claypan watersheds. Journal of Soil and Water Conservation 73(2):189-199, doi:10.2489/jswc.73.2.189.

Sadler, E.J., R.N. Lerch, N.R. Kitchen, S.H. Anderson, C. Baffaut, K.A. Sudduth, A.A. Prato, R.J. Kremer, E.D Vories, D.B. Myers, R. Broz, R.J. Miles, and FJ. Young. 2015. Long-term agroecosystem research in the Central Mississippi River Basin: Introduction, establishment, and overview. Journal of Environmental Quality 44(1):3-12.

SAS Institute Inc. 2011. Statistical Analysis System. Cary, NC: SAS Institute Inc.

Smith, D.R., W. Francesconi, S.J. Livingston, and C. Huang. 2015. Phosphorus losses from monitored fields with conservation practices in the Lake Erie Basin, USA AMBIO 44(2):319-331

Smith, D.R., R.S. Wilson, K.W. King, M. Zwonitzer, J.M McGrath, R.D. Harmel, R.L. Haney, and L.T. Johnson. 2018. Lake Erie, phosphorus, and microcystin: Is it really the farmer's fault? Journal of Soil and Water Conservation 73(1):48-57, doi:10.2489/jswc.73.1.48.

Spooner, J., R.P. Maas, S.A. Dressing, M.D. Smolen, and F.J. Humenik. 1985. Appropriate designs for documenting water quality improvements from agricultural NPS control programs. In Perspective on Nonpoint Source Pollution. Proceedings of a National Conference, Kansas City, Missouri, May 19-22, 1985. Washington, DC: US Environmental Protection Agency.

Udawatta, R.P., H.E. Garrett, and R. Kallenbach. 2011. Agroforestry buffers for nonpoint source pollution reductions from agricultural watersheds. Journal of Environmental Quality 40(3):800-806.

USDA NRCS (Natural Resources Conservation Service).

2006. Land resource regions and major land resource areas of the United States, the Caribbean, and the Pacific Basin. Washington, DC: USDA Natural Resources Conservation Service.

USDA NRCS. 2009. Variable-rate nitrogen fertilizer application in corn using in-field sensing of leaves or canopy. Missouri NRCS Agronomy Technical Note MO-35. Columbia, MO: University of Missouri Extension. http://extension.missouri. edu/sare/documents/AgronomyTechnicalNote2012.pdf.

Vance, E.D., P.C. Brookes, and D.S. Jenkinson. 1987. An extraction method for measuring soil microbial biomass C. Soil Biology and Biochemistry 19:703-707.

Verbree, D.A., S.W. Duiker, and P.J.A. Kleinman. 2010. Runoff losses of sediment and phosphorus from no-till and cultivated soils receiving dairy manure. Journal of Environmental Quality 39(5):1762-1770.

Veum, K.S., R.J. Kremer, K.A. Sudduth, N.R. Kitchen, R.N Lerch, C. Baffaut, D.E. Stott, D.L. Karlen, and E.J. Sadler. 2015. Conservation effects on soil quality indicators in the Missouri Salt River Basin. Journal of Soil and Water Conservation 70(4):232-246, doi:10.2489/ jswc.70.4.232.

Willett, C.D., R.N. Lerch, C.H. Lin, K.W. Goyne, N.D. Leigh, and C.A. Roberts. 2016. Benzoxazinone-mediated triazine degradation: A proposed reaction mechanism. Journal of Agricultural and Food Chemistry 64:4858-4865.

Willett, C.D., R.N. Lerch, R.C. Schultz, S.A. Berges, R.D. Peacher, and T.M. Isenhart. 2012. Streambank erosion in two watersheds of the Central Claypan Region of Missouri, United States. Journal of Soil and Water Conservation 67(4):249-263, doi:10.2489/jswc.67.4.249.

Yost, M.A., N.R. Kitchen, K.A. Sudduth, R.E. Massey, E.J. Sadler, S.T. Drummond, and M.R. Volkmann. 2019. A long-term precision Agriculture system sustains grain profitability. Precision Agriculture 20:1177-1198.

Yost, M.A., N.R. Kitchen, K.A. Sudduth, E.J. Sadler, S.T. Drummond, and M.R. Volkmann. 2017. Long-term impact of a precision agriculture system on grain crop production. Precision Agriculture 18(5):823-842.

Zablotowicz, R.M., L.J. Krutz, K.R. Reddy, M.A. Weaver, C.H. Koger, and M.A. Locke. 2007. Rapid development of enhanced atrazine degradation in a Dundee silt loam soil under continuous corn and in rotation with cotton. Journal of Agricultural and Food Chemistry 55:852-859.

Zeimen, M.B., K.A. Janssen, D.W. Sweeney, G.M Pierzynski, K.R. Mankin, D.L. Devlin, D.L. Regehr, M.R. Langemeier, and K.A. McVay. 2006. Combining management practices to reduce sediment, nutrients, and herbicides in runoff. Journal of Soil and Water Conservation 61(5):258-267.

Zhu, J.C., C.J. Gantzer, S.H. Anderson, E.E. Alberts, and P.R. Beuselinck. 1989. Runoff, soil, and dissolved nutrient losses from no-till soybean with winter cover crops. Soil Science Society of America Journal 53:1210-1214. 